\title{
Effect of salinity stress on biochemical constituents and ArHsp22 gene expression in Artemia franciscana
}

\author{
P. A. VIKAS ${ }^{1}$, P. C. THOMAS ${ }^{2}$, N. K. SAJESHKUMAR ${ }^{2}$, KAJAL CHAKRABORTY², N. K. SANIL ${ }^{2}$ \\ AND K. K. VIJAYAN ${ }^{3}$ \\ ${ }^{1}$ Krishi Vigyan Kendra of ICAR - Central Marine Fisheries Research Institute, Narakkal, Kochi - 682 505, Kerala, India \\ ${ }^{2}$ ICAR - Central Marine Fisheries Research Institute, Ernakulam North P.O., Kochi - 682 018, Kerala, India \\ ${ }^{3}$ ICAR - Central Institute of Brackishwater Aquaculture, \#75, Santhome High Road, Raja Annamalai Puram, \\ Chennai - 600 028, Tamil Nadu, India \\ e-mail:vikaspattath@gmail.com
}

\begin{abstract}
The present study analysed the effect of salinity stress on survival, biochemical constituents such as soluble protein, amino acid, trehalose and fatty acid, as well as real time expression of the Artemia heat-shock protein 22 (ArHsp 22) gene in Artemia franciscana. Results of the study revealed that Artemia can withstand sudden salinity increase up to $200 \mathrm{ppt}$ without any mortality up to $6 \mathrm{~h}$. Significantly higher mortality percentage was recorded at $24 \mathrm{~h}$ of incubation at $200 \mathrm{ppt}$. Short-term exposure to hypersaline conditions significantly reduced the protein content in Artemia while the protein biosynthesis enhanced after $24 \mathrm{~h}$ of incubation at $150 \mathrm{ppt}$ salinity. Long term exposure to $200 \mathrm{ppt}$ salinity did not show any further increase in amino acid content as observed at 100 and $150 \mathrm{ppt}$ conditions, indicating reduced rate of amino acid metabolism and stress. Salt stress induced the synthesis of total polyunsaturated fatty acids (PUFA) in Artemia especially the 22:6n-3 and 20:5n-3 after $24 \mathrm{~h}$ of incubation at $150 \mathrm{ppt}$. Exposure to higher salinity induced trehalose production which indicated its vital role in combating salt stress in Artemia. The present study also indicated that short-term salt stress can significantly enhance the ArHsp22 gene expression in Artemia adults.
\end{abstract}

Keywords: Amino acid, ArHsp22 gene, Carotenoid, Fatty acid, Salt stress, Trehalose

Aquatic animals are more susceptible to sudden variations in the living medium than the land animals as it is essential for them to maintain osmotic balance. Both, marine and freshwater organisms possess different mechanisms to cope up with the varying environmental conditions. The brine shrimp, Artemia are distributed along the hypersaline, inland salt lakes and salt pans around the globe (Vikas et al., 2012; 2014) They are rarely found in waters with salinity lower than $45 \mathrm{ppt}$, although physiologically they thrive in seawater and even in brackishwater. Salinity is without any doubt the predominant abiotic factor determining the presence of Artemia and the natural defense mechanism against predators, consequently limiting its geographical distribution. In Artemia, different adaptation mechanisms are prominent to overcome the extreme environmental conditions mainly through the biosynthesis of osmotically active compounds, cryoprotectants/thermoprotectants, polyols, amino acids, quaternary ammonium salts and disaccharides (Yancey et al., 1982). During stress, molecular chaperones interact with other proteins to modulate folding, cell localisation and functionality and to protect against irreversible denaturation, and the small heat shock proteins (sHsp's) are known for their protective capability, representing the first line of defense against physiological and environmental stress. Gene expressions of sHsp are either stress induced or in specific cells and tissues, independent of or concomitant with, stress exposure. The objectives of the present study was to understand the effect of salinity stress on the survival rate, biochemical constituents such as soluble protein, amino acid, trehalose as well as fatty acid and to examine the real time expression of ArHsp 22 in Artemia franciscana. Artemia cysts were collected from the hypersaline habitats

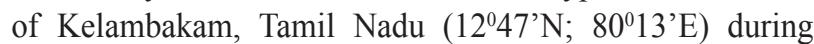
June 2010. The samples were brought to the wet laboratory of ICAR-Central Marine Fisheries Research Institute (ICAR-CMFRI), Kochi, India, suitably cleaned, processed by bipartial floatation technique with brine and freshwater and stored under refrigeration until further use. Decapsulation and hatching of Artemia cysts (strain designation CKF) was performed following Sorgeloos et al. (1986) with suitable modifications. Freshly hatched nauplii were harvested and stocked in fiber reinforced plastic (FRP) tanks (1 t) holding seawater of salinity $50 \%$ (temperature $23 \pm 1^{\circ} \mathrm{C}$ ). Ten percent of the culture medium was exchanged daily with fresh seawater and the nauplii were fed ad libitum for 16 days with Isochrysis galbana. 
Experiments were designed to study the biochemical and genetic variations in Artemia subjected to salt stress at four different saline conditions (50, 100, 150 and $200 \mathrm{ppt}$ ) for 0, 1, 6 and $24 \mathrm{~h}$ durations. Experimental rearing medium at different salinity concetrations were prepared by diluting $6 \mathrm{M}$ sodium chloride (Sigma) solution in distilled water and stocked with Artemia. Adult Artemia (1000 males and 1000 females) were randomly harvested from the FRP tanks and stocked (@1 individual per $10 \mathrm{ml}$ ) in glass tanks holding saline solution (20 l) at concetrations of 50 (T1), 100 (T2), 150 (T3) and $200 \mathrm{ppt}$ (T4), each in triplicates. Artemia maintained at $50 \mathrm{ppt}$ (T1) was considered as control.

Prior to the experiment, Artemia individuals were acclimatised to experimental conditions by progressively increasing (in 60-70 min) the salinity to desired levels in all treatments. All the treatments (T1 to T4) were provided with optimum aeration, light $(1500 \mathrm{Lux})$, temperature $\left(23 \pm 1^{\circ} \mathrm{C}\right)$ and the Artemia were fed I. galabana (45x $10^{6}$ cells $\left.\mathrm{ml}^{-1}\right)$.

The survival of Artemia in different treatments (T1 to T4) were checked after 6 and $24 \mathrm{~h}$ of incubation. The survival percentages in all treatments were calculated using the formula:

Survival percentage $=[$ Total number of live animals $] /($ Total number of live animals + Total number of dead animals)] X 100.

Artemia samples were harvested from all treatment tanks after 6 and $24 \mathrm{~h}$ of incubation for various analyses. Samples for the biochemical estimations were harvested, lyophilised (Martin Christ Alpha-1-4 LD freeze-drier, Osterode, Germany) and stored at $-80^{\circ}$ until analysed. Samples for gene expression study (30 individuals) were preserved in separate vials with RNA later solution ( $0.6 \mathrm{ml})$ (Sigma Aldrich, USA). All analyses were carried out in triplicates.

Soluble protein content of the lyophilised Artemia samples (100 mg) were estimated as per Lowry et al. (1951). Total carotenoid content of each lyophilised samples (100 $\mathrm{mg}$ ) were determined following Tolasa et al. (2005) and Olson (1979). Amino acid content of the Artemia samples was estimated following the Pico-Tag method (Heinrikson and Meredith, 1984). Trehalose content was estimated following established methods (Jermyn, 1975, Carpenter and Hand, 1986), with suitable modifications. Total lipid (500 mg) was extracted with $\mathrm{CHCl}_{3} / \mathrm{MeOH}(60 \mathrm{ml}, 2: 1, \mathrm{v} / \mathrm{v})$ and water $(20 \mathrm{ml})$ (Bligh and Dyer 1959). The $\mathrm{CHCl}_{3}$ layer was processed to recover triglycerides and saponified with alkaline reagent ( $3 \mathrm{ml}, 0.5 \mathrm{~N} \mathrm{KOH} / \mathrm{MeOH}$ ). The saponified materials were reacted with the methylating mixture $\left(14 \% \mathrm{BF}_{3} / \mathrm{CH}_{3} \mathrm{OH}\right)$ to yield methyl esters (FAME) and subsequently extracted with $n$-hexane $/ \mathrm{H}_{2} \mathrm{O}(1: 2, \mathrm{v} / \mathrm{v})$ mixture (Metcalfe et al., 1966). Aqueous layer was removed and the $n$-hexane layer was recovered and concentrated in vacuum, reconstituted in petroleum ether and stored at $-20^{\circ} \mathrm{C}$. Fatty acid composition was analysed using a Perkin Elmer Auto System XL, Gas chromatograph (Perkin Elmer, USA) equipped with a flame ionisation detector.

Total RNA from individual adult Artemia were extracted using the GenElute ${ }^{\mathrm{TM}}$ Mammalian Total RNA Miniprep kit (Sigma Aldrich, USA), following manufacturer's instructions, and stored at $-80^{\circ} \mathrm{C}$. Real time RT-PCR was carried out to study the expression of ArHsp22 along with expression of the house keeping genes $\beta$ actin and GADPH from the cDNA using the gene specific primers.

Statistical analysis of the data was carried by analysis of variance (ANOVA) and the means of all parameters were compared using Duncan's multiple range tests. All statistical analyses were performed with SPSS programme ver. 13.0 (SPSS Inc, Chicago, USA).

The present study revealed that Artemia can withstand sudden increase in salinity up to $150 \mathrm{ppt}$ (T3) without any mortality up to $6 \mathrm{~h}$. Low percentage of mortality was noticed during further incubation at $150 \mathrm{ppt}$ up to $24 \mathrm{~h}$.. But at $200 \mathrm{ppt}$ (T4), it was observed that they can survive with low percentage mortality up to $6 \mathrm{~h}$ incubation, while significantly higher mortality percentage was recorded at $24 \mathrm{~h}$ of incubation (Fig. 1). Though Artemia are naturally present in hypersaline environments (above $200 \mathrm{ppt}$ ), sudden increase in salinity can act as a stress factor which in turn can make them unfit to survive.

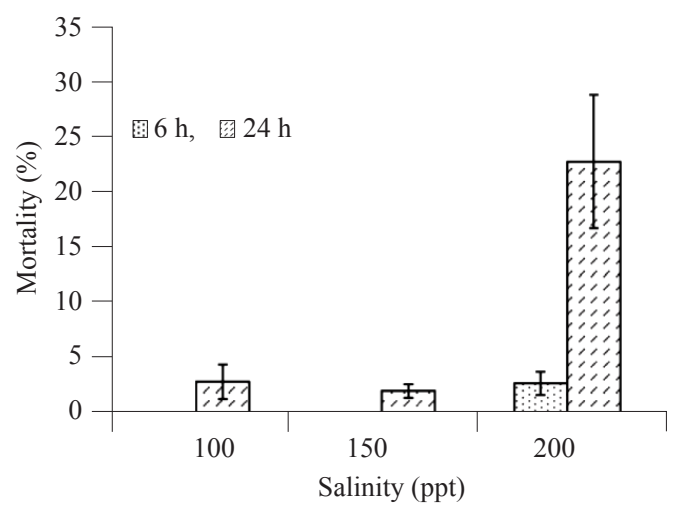

Fig. 1. Mortality percentage of Artemia exposed to different saline conditions after 6 and $24 \mathrm{~h}$ of incubation

Short term exposure under hypersaline conditions (150 ppt and above) significantly reduced the protein content in Artemia while the protein biosynthesis enhanced after $24 \mathrm{~h}$ of incubation in Artemia maintained at $150 \mathrm{ppt}$ salinity. The initial reduction in protein content may be due to the increasing activity of acid and alkaline proteases (Parida et al., 2004). The enhanced production of soluble protein after long term exposure could be attributed to over production of small heat shock proteins (sHsp 21, Hsp 22 and p 26) in Artemia to overcome the stressed environment which is 
the characteristic mechanism exhibited by the diapausing organisms for achieving reversible dormancy (Qiu and Macrae, 2008). Protein degradation in animal tissues may vary individually due to the physical conformation and other properties of the protein complex. The large proteins are more susceptible to degradation than smaller ones and also the rate of degradation will be more in acidic proteins than neutral or basic proteins (Dice et al., 1979). In Artemia, sHsp's form distinctive molecular chaperones characterised by monomers ranging from 12 to $43 \mathrm{kDa}$. sHsp's have well defined role in preventing irreversible protein denaturation, apoptosis resistance, modulation of actin assembly as well as microfilament stability, conferring thermo tolerance on cells. This was found to be a well known phenomenon in plants also where the salt stress induces quantitative and qualitative changes in protein content of the cells (Wimmer, 2003).

The present study revealed the amino acid synthesis ability of Artemia to overcome salt stress (Fig. 2.)
Accumulation or overexpression of nitrogen containing compounds (proline, other amino acids, quaternary amino compounds and polyamines) and hydroxyl compounds metabolites in plants, algae, fungi and bacteria under salt stress are common (Csonka, 1989). Long-term exposure at $200 \mathrm{ppt}$ salinity did not show any further increase in amino acid content as observed at 100 and 150 ppt which indicates reduction in amino acid metabolism due to sudden exposure to hypersaline condition.

The key aspect of fatty acid dynamics in Artemia and other zooplankton is whether they are able to modify the dietary fatty acids obtained from the exogenous dietary source. Salt stress induced the synthesis of total polyunsaturated fatty acids (PUFA) in Artemia especially the 22:6n-3 and 20:5n 3 after $24 \mathrm{~h}$ incubation at $150 \mathrm{ppt}$ (Table 1).

Conversion of 18: 2 n-3 to 20: 5 n-3 in Artemia is clearly evident from the fatty acid data under different salinities, where the 18: $2 n-3$ content reduced and 20: $5 n-3$ increased

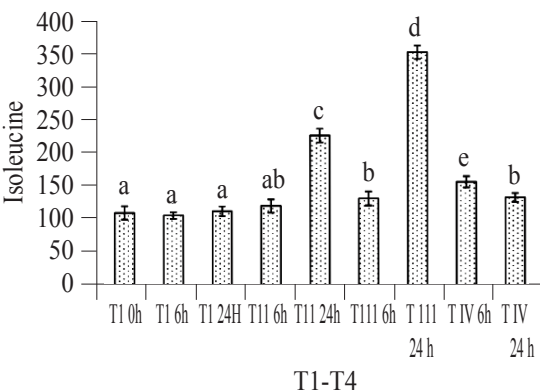

(a)

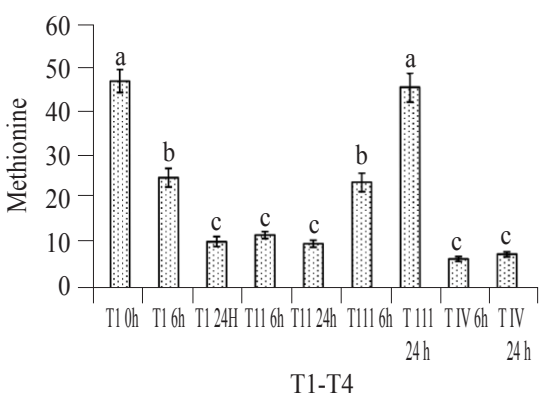

(d)

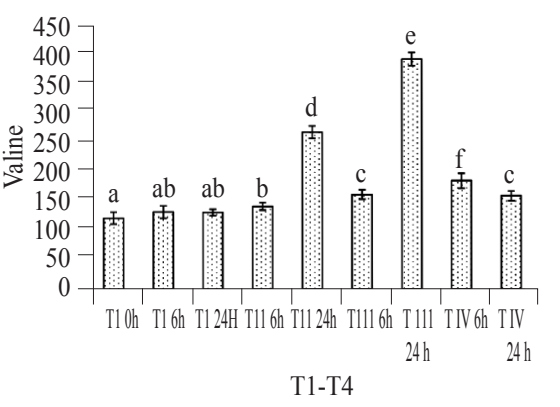

(g)

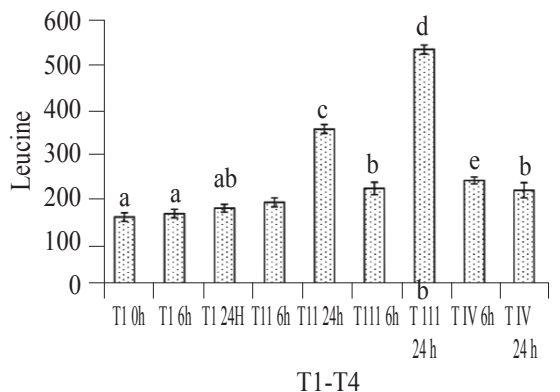

(b)

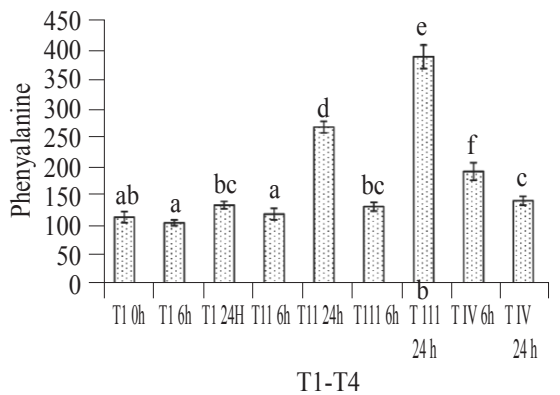

(e)

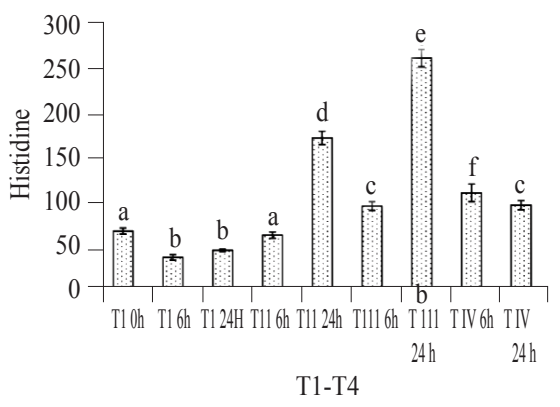

(h)

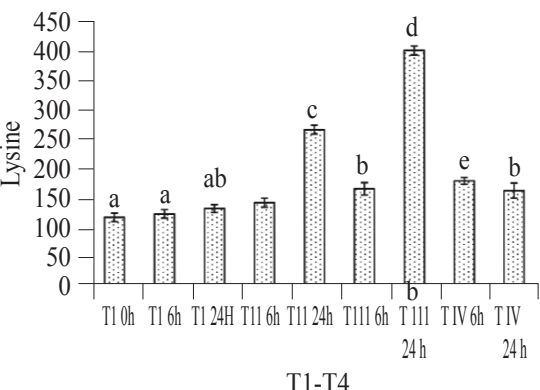

(c)

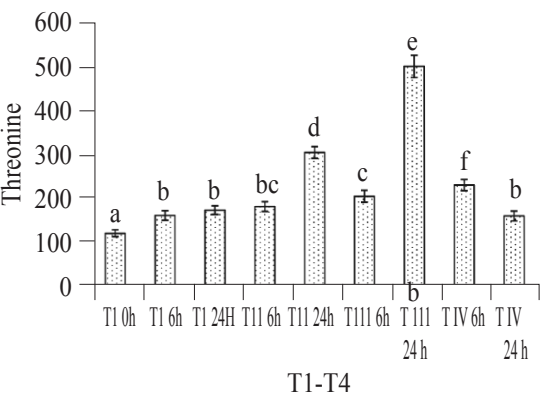

(f)

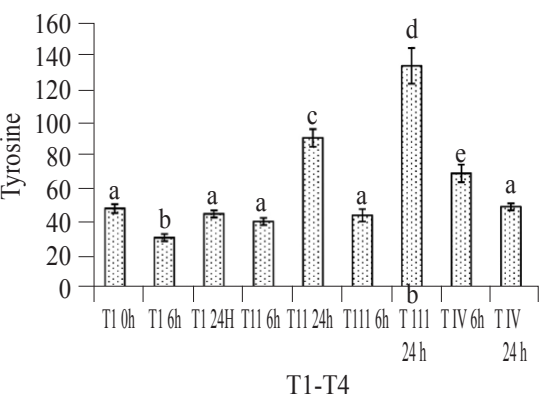

(i)

Fig. 2. Indispensible amino acid content in Artemia exposed to different saline conditions after 6 and $24 \mathrm{~h}$ of incubation 
Table 1. Fatty acid content of Artemia under different salinity conditions

\begin{tabular}{|c|c|c|c|c|c|c|c|c|c|}
\hline Fatty acid & $50 \% 0 \mathrm{~h}$ & $50 \% 06 \mathrm{~h}$ & $50 \%$ o $24 \mathrm{~h}$ & $100 \%$ o h & $100 \%$ o $24 \mathrm{~h}$ & $150 \% 06 \mathrm{~h}$ & $150 \%$ o $24 \mathrm{~h}$ & $200 \%$ o $6 \mathrm{~h}$ & $200 \%$ o $24 \mathrm{~h}$ \\
\hline $12: 00$ & 0.14 & 1.17 & 3.90 & 0.55 & 0.93 & 1.95 & 1.15 & 2.29 & 0.55 \\
\hline $13: 00$ & 0.14 & 0.32 & 0.30 & 0.21 & 0.17 & 0.65 & 0.04 & 0.18 & 0.27 \\
\hline $14: 00$ & 3.87 & 3.37 & 4.39 & 4.71 & 6.10 & 6.52 & 5.24 & 3.55 & 4.45 \\
\hline $15: 00$ & 0.32 & 7.19 & 0.90 & 5.62 & 0.41 & 0.28 & 0.15 & 0.40 & 1.03 \\
\hline $16: 00$ & 18.84 & 20.59 & 20.89 & 18.03 & 18.98 & 16.66 & 15.00 & 22.17 & 19.10 \\
\hline $17: 00$ & 1.21 & 0.97 & 3.40 & 3.19 & 2.55 & 0.74 & 2.30 & 1.21 & 3.49 \\
\hline $18: 00$ & 7.41 & 8.87 & 8.60 & 7.21 & 8.30 & 6.89 & 6.81 & 9.35 & 8.15 \\
\hline 20:00 & 1.38 & 0.78 & 1.40 & 0.90 & 0.87 & 0.84 & 0.80 & 1.12 & 0.75 \\
\hline $22: 00$ & 1.03 & 1.04 & 0.80 & 1.80 & 0.87 & 0.84 & 2.07 & 0.54 & 0.27 \\
\hline $24: 00$ & 0.74 & 0.32 & 0.20 & 0.35 & 0.17 & 0.47 & 0.27 & 1.08 & 0.21 \\
\hline$\sum \mathrm{SFA}$ & 35.08 & 44.62 & 44.78 & 42.57 & 39.35 & 35.84 & 33.83 & 42.00 & 38.27 \\
\hline $14: 1 \mathrm{n} 7$ & 3.94 & 1.10 & 5.80 & 0.49 & 4.53 & 7.26 & 4.02 & 5.76 & 5.75 \\
\hline $16: \ln 7$ & 6.99 & 4.14 & 3.40 & 4.02 & 4.47 & 3.35 & 3.52 & 2.92 & 3.15 \\
\hline $18: \ln 9$ & 18.98 & 19.95 & 15.99 & 14.63 & 26.12 & 12.38 & 14.92 & 18.89 & 16.02 \\
\hline 17:01 & 0.50 & 1.10 & 1.90 & 1.18 & 0.35 & 1.68 & 1.19 & 0.54 & 0.68 \\
\hline $20: \ln 11$ & 0.50 & 0.39 & 0.70 & 1.04 & 0.87 & 1.86 & 0.99 & 1.26 & 2.40 \\
\hline$\sum$ MUFA & 30.91 & 26.68 & 27.79 & 21.36 & 36.34 & 26.53 & 24.64 & 29.00 & 28.00 \\
\hline $18: 2 \mathrm{n} 6$ & 4.43 & 4.34 & 4.60 & 4.16 & 4.24 & 3.26 & 4.13 & 2.56 & 3.63 \\
\hline $18: 3 n 6$ & 3.83 & 4.08 & 3.10 & 4.30 & 3.89 & 2.89 & 4.06 & 2.11 & 3.08 \\
\hline $18: 3 n 3$ & 0.89 & 2.07 & 1.50 & 1.59 & 1.22 & 2.79 & 1.07 & 1.80 & 1.71 \\
\hline 20: $2 \mathrm{n} 6$ & 3.90 & 3.89 & 1.90 & 5.48 & 4.93 & 2.98 & 6.16 & 3.37 & 4.11 \\
\hline $20: 3 \mathrm{n} 6$ & 0.92 & 0.52 & 0.60 & 0.97 & 0.35 & 1.21 & 0.92 & 3.37 & 1.10 \\
\hline $20: 4 n 6$ & 0.67 & 1.36 & 1.00 & 1.53 & 0.29 & 1.30 & 0.96 & 0.94 & 1.03 \\
\hline $20: 5 n 3$ & 3.55 & 3.11 & 3.90 & 4.58 & 2.03 & 4.00 & 3.63 & 0.67 & 4.31 \\
\hline $22: 5 n 3$ & 3.02 & 0.91 & 2.70 & 1.66 & 0.29 & 2.14 & 1.19 & 0.45 & 0.96 \\
\hline $22: 6 n 3$ & 6.10 & 3.04 & 4.70 & 7.63 & 3.72 & 12.29 & 10.14 & 6.03 & 6.30 \\
\hline$\sum$ PUFA & 27.31 & 23.32 & 24.00 & 31.90 & 20.96 & 32.86 & 32.26 & 21.00 & 26.23 \\
\hline$\sum \mathrm{n} 3$ & 13.56 & 9.13 & 12.80 & 15.46 & 7.26 & 21.22 & 16.03 & 8.95 & 13.28 \\
\hline$\sum \mathrm{n} 6$ & 13.75 & 14.19 & 11.20 & 16.44 & 13.70 & 11.64 & 16.23 & 12.35 & 12.95 \\
\hline$\sum$ C18PUFA & 9.15 & 10.49 & 9.20 & 10.05 & 9.35 & 8.94 & 9.26 & 6.47 & 8.42 \\
\hline$\sum$ C20PUFA & 9.04 & 8.88 & 7.40 & 12.56 & 7.60 & 9.49 & 11.67 & 8.35 & 10.55 \\
\hline $\mathrm{n} 3 / \mathrm{n} 6$ & 0.99 & 0.64 & 1.14 & 0.94 & 0.53 & 1.82 & 0.99 & 0.72 & 1.03 \\
\hline$\sum \mathrm{PUFA} / \sum \mathrm{SFA}$ & 0.78 & 0.52 & 0.54 & 0.75 & 0.53 & 0.92 & 0.95 & 0.50 & 0.69 \\
\hline EPA/AA & 5.30 & 2.29 & 3.90 & 2.99 & 7.00 & 3.08 & 3.78 & 0.71 & 4.18 \\
\hline$\sum \mathrm{DHA} / \sum \mathrm{EPA}$ & 1.72 & 0.98 & 1.21 & 1.67 & 1.83 & 3.07 & 2.79 & 9.00 & 1.46 \\
\hline
\end{tabular}

than the control at 100 and $150 \mathrm{ppt}$. This indicates the increased activity of elongases and $\Delta 5$-desaturase at $100 \mathrm{ppt}$ to biosynthesise 20:5n-3 from 18:3n-3.

Exposure to higher salinity induced trehalose production (Table 2) which indicates its vital role in salt stress resistance in Artemia. Hare et al. (1998) reported that trehalose functions as compatible solute in the stabilisation of biological structures and serve as osmoprotectants under abiotic stress. Trehalose may also stabilise the dehydration of enzymes, proteins and lipid membranes efficiently. Pelah et al. (2004) and Czygan (1964) reported that stress can induce the biosynthesis of secondary carotenoids astaxanthin, canthaxanthin and the total secondary carotenoids. Adaptive advantages of Artemia for enhanced production and accumulation of carotenoids in tissues have been reported in earlier studies. Soejima et al. (1980) reported that the canthaxanthins form the major carotenoid and have specific role in photoprotective function. Carotenoid content of Artemia showed increased production when exposed to 100 and $150 \mathrm{ppt}$ and it was down regulated at 200 ppt (Table 2).

ArHsp22 is the third sHsp identified in Artemia cysts after ArHsp21 and p26 and it possesses an $\alpha$ crystalline domain flanked by variable amino and carboxyl terminals, all with characteristic sequence properties (Qiu and Macrae, 2008). Though ArHsp22 synthesis is developmentally regulated, heat shock can induce the production in adults, in contrast to ArHsp21 and p26 gene expression. ArHsp22, 
Table 2. Trehalose, protein and carotenoid content of Artemia exposed to different salinity conditions

\begin{tabular}{|c|c|c|c|}
\hline Artemia culture condition & Protein $(\%)$ & Carotenoid $\left(\mu \mathrm{g} \mathrm{g}^{-1}\right)$ & Trehalose $(\%)$ \\
\hline $50 \% 0 \mathrm{~h}$ & $22.56 \pm 0.04^{\mathrm{a}}$ & $154.84 \pm 1.11^{\mathrm{a}}$ & $2.50 \pm 0.08^{\mathrm{a}}$ \\
\hline $50 \%$ o $6 \mathrm{~h}$ & $21.89 \pm 0.03^{\mathrm{a}}$ & $158.71 \pm 1.08^{\mathrm{a}}$ & $2.49 \pm 0.08^{\mathrm{a}}$ \\
\hline $50 \%$ o $24 \mathrm{~h}$ & $22.02 \pm 0.04^{\mathrm{a}}$ & $159.65 \pm 1.06^{\mathrm{ac}}$ & $2.56 \pm 0.08^{\mathrm{ab}}$ \\
\hline $100 \%$ o h & $24.41 \pm 0.1^{\mathrm{a}}$ & $126.95 \pm 1.50^{\mathrm{b}}$ & $4.66 \pm 0.35^{b}$ \\
\hline $100 \%$ 24 h & $22.88 \pm 0.02^{\mathrm{a}}$ & $199.76 \pm 1.09^{c}$ & $4.29 \pm 0.77^{\mathrm{cf}}$ \\
\hline $150 \% 06 \mathrm{~h}$ & $16.75 \pm 0.01^{\mathrm{bcd}}$ & $151.45 \pm 1.03^{\mathrm{d}}$ & $3.60 \pm 1.18^{\mathrm{d}}$ \\
\hline $150 \%$ 24 h & $23.24 \pm 0.01^{\mathrm{a}}$ & $200.34 \pm 0.50^{\mathrm{e}}$ & $4.74 \pm 0.92^{\mathrm{e}}$ \\
\hline $200 \%$ o $6 \mathrm{~h}$ & $18.67 \pm 0.01^{\mathrm{cb}}$ & $103.76 \pm 1.09^{\mathrm{f}}$ & $4.24 \pm 0.34^{\mathrm{f}}$ \\
\hline $200 \% 24 \mathrm{~h}$ & $15.24 \pm 0.08^{\mathrm{dc}}$ & $110.71 \pm 1.08^{\mathrm{g}}$ & $2.61 \pm 0.07^{\mathrm{a}}$ \\
\hline
\end{tabular}

$\beta$ actin and GADPH gene expression were analysed by SYBR ${ }^{\circledR}$ Green I based real-time RT-PCR. PCR efficiency of three genes is presented in Fig. 3. Melt curve dissociation analysis showed single peak in ArHsp22, $\beta$ actin and GAPDH gene indicating the specificity of the reaction (Fig. 4.). The normalised expression of ArHsp 22 gene in Artemia showed a gradual increase at $100 \mathrm{ppt}$ salinity after $6 \mathrm{~h}$ of incubation. While under 150 and 200 ppt saline conditions, it showed a sharp increase and recorded maximum expression at $150 \mathrm{ppt}$ after the first $6 \mathrm{~h}$ of incubation. However the ArHsp22 gene expression was considerably reduced in 100, 150 and $200 \mathrm{ppt}$ saline conditions after $24 \mathrm{~h}$ of incubation when compared to the $6 \mathrm{~h}$ expression (Fig. 5.). Irrespective of incubation time, the normalised expression of ArHsp22 gene was high in 150 ppt salinity incubated Artemia.

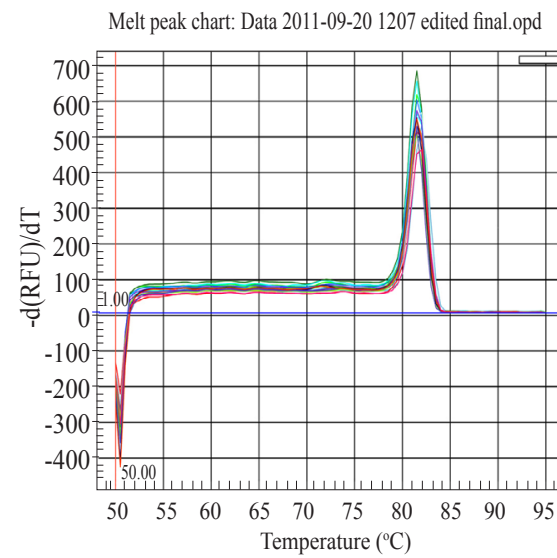

(a)

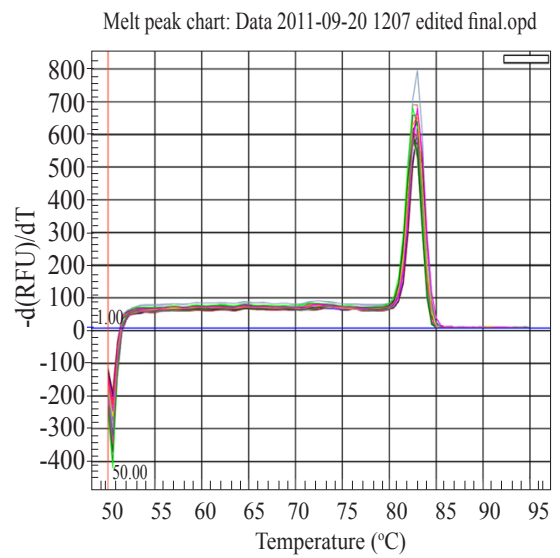

(b)

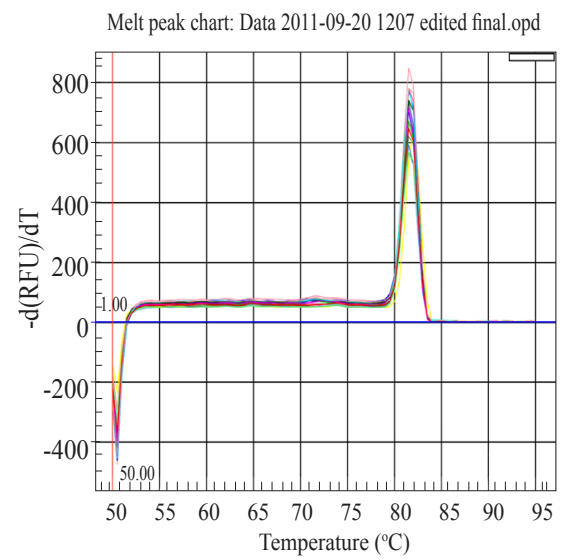

(c)

Fig. 3. PCR efficiency of ArHsp22, $\beta$ actin and GAPDH genes

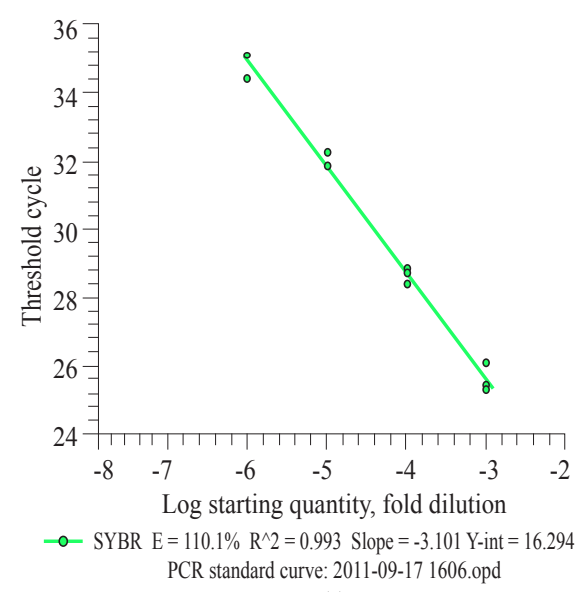

(a)

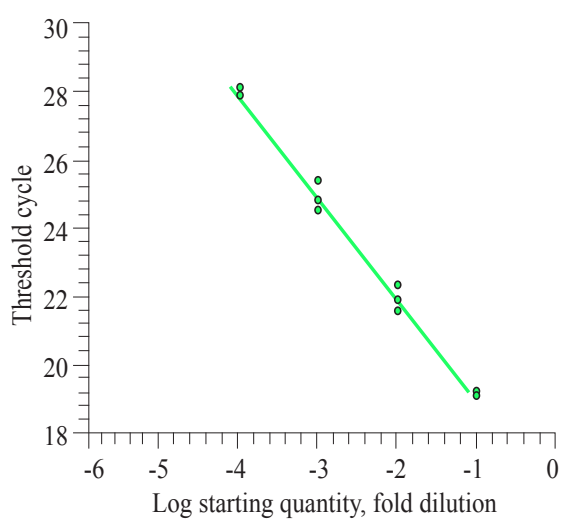

Log starting quantity, fold dilution
$-0-$ SYBR $E=110.6 \% R^{\wedge} 2=0.991$ Slope $=-3.092$ Y-int $=15.502$ PCR standard curve: Graph data 2011-09-19 1118.opd (b)

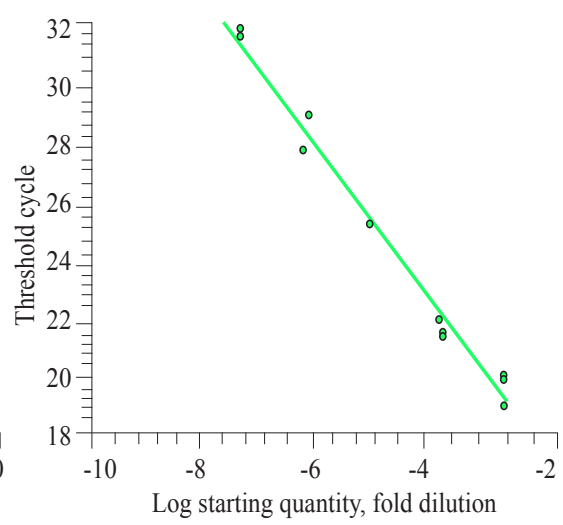

$\mathrm{E}=110.9 \% \mathrm{R}^{\wedge} 2=0.990$ Slope $=-3.085$ Y-int $=9.978$ PCR standard curve: Beta actin final.opd

(c)

Fig. 4. Melt curve dissociation analysis of ArHsp22, $\beta$ actin and GAPDH genes 
Normalisation of the target gene expression is an essential component of a reliable qPCR assay because this process controls for variations in extraction yield, reversetranscription yield and efficiency of amplification, thus enabling comparisons of mRNA concentrations across different samples (Bustin et al., 2009). According to Huggett et al. (2005), the use of reference genes as internal controls

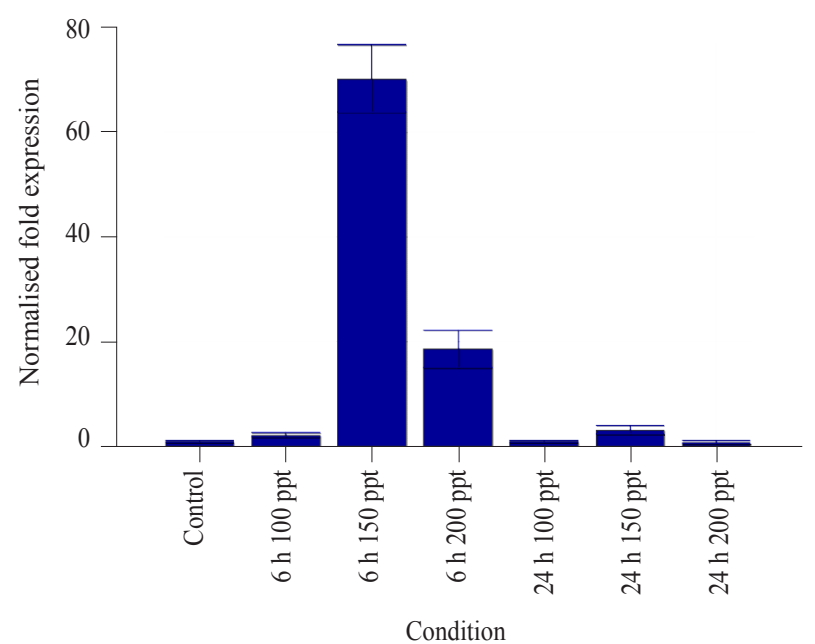

Fig. 5. ArHsp22 gene expression in Artemia incubated under different salinity conditions

is the most common and accepted method for the most appropriate normalisation of cellular mRNA data. ArHsp22 gene expression was normalised with the housekeeping gene GADPH and $\beta$ actin using SYBR ${ }^{\circledR}$ Green I, and the analysis revealed variation in ArHsp22 gene expression with salinity in Artemia. Study indicated that short-term salt stress can significantly enhance the ArHsp22 gene expression in Artemia adults. The ArHsp22 chaperones prevent irreversible, stress induced protein denaturation and act as the first line of defense against salt stress. Though ArHsp22 lack typical nuclear localisation signal, they migrate into the nucleus by association with proteins possessing a nuclear localisation signal or if retained may preferentially interact with an intranuclear component such as the lamins/nuclear matrix (Qiu and Macrae, 2008).

Results of the present study revealed that Artemia can withstand sudden increase in salinity up to $150 \mathrm{ppt}$ without any mortality up to $6 \mathrm{~h}$, and with low levels of mortality up to $24 \mathrm{~h}$ incubation. Enhanced expression of biochemical constituents such as protein, trehalose, carotenoid and fatty acid in Artemia might have contributed towards protection of cell membranes and biomolecules from the salt stress. Further, ArHsp 22 gene expression might have acted as the first line of defense against the sudden salinity stress in Artemia.

\section{Acknowledgements}

The authors are thankful to the Director, ICAR-Central Marine Fisheries Research Institute (ICAR-CMFRI), Kochi, India for providing necessary facilities to carry out the work. The senior author thankfully acknowledges the funding support from the Department of Biotechnology (DBT), Government of India. Thanks are due to Mr. P. Shiju for the help rendered in laboratory works and to Mrs. Shylaja for amino acid analysis at ICAR-CMFRI, Kochi, India.

\section{References}

Bligh, E. G. and Dyer, W. J. 1959. A rapid method of total lipid extraction and purification., Can J. Biochem Physiol., 37: 911-917.

Bustin, S., Benes, V., Garson, J., Hellemans, J., Huggett, J., Kubista, M. and Mueller, R. 2009. The MIQE guidelines: minimum information for publication of quantitative real-time PCR experiments. Clin. Chem., 55(4): 611-22.

Carpenter, J. F. and Hand, S. C. 1986. Arrestment of carbohydrate metabolism during anaerobic dormancy and aerobic acidosis in Artemia embryos: determination of $\mathrm{pH}$-sensitive control points. J. Comp. Physiol,, Part B. 156(4): 451-459.

Chrousos, G. P. and Gold, P. W. 1992. The concepts of stress and stress system disorders. Overview of physiological and behavioural homeostasis. J. Am. Med. Ass., 267: 1244-1252.

Csonka, L. 1989. Physiological and genetic responses of bacteria to osmotic stress. Microbiol. Rev., 53: 121-147.

Czygan, F. C. 1964. Canthaxanthin als sekundar - Carotenoid einiger Grunalgen. Experientia, 20: 575-577.

Dice, J. F., Hess, E. J. and Goldberg, A. L. 1979. Studies on the relationship between the degradative rates of proteins in vivo and their isoelectric points. Biochem. J., 178(2): 305-312

Hare, P. D., Cress, W. A. and van, Staden, J. 1998. Dissecting the roles of osmolyte accumulation during stress. Plant, Cell Environ., 21: 535-553.

Heinrikson, R. L. and Meredith, S. C. 1984. Amino acid analysis by reverse phase high performance liquid chromatography precolumn derivatisation with phenylisothiocianate. Anal. Biochem., 136(1): 65-71.

Huggett, J., Dheda, K., Bustin, S. and Zumla, A. 2005. Real-time RT-PCR normalisation: Strategies and considerations. Genes Immun., 6: 279-284.

Jermyn, M. A. 1975. Increasing the sensitivity of the anthrone method for carbohydrate. Anal. Biochem., 68: 33-335.

Lowry, O. H., Rosebrough, N. J., Farr, A. L. and Randall, R. J. 1951. Protein measurement with the folin phenol reagent. J. Biol. Chem., 193: 265.

Metcalfe, L. D., Schimtz, A. A. and Pelka, J. R. 1966. Rapid preparation of fatty acid esters from lipids for gas chromatographic analyses. Anal. Chem., 38: 514-515. 
Olson, A. 1979. A simple dual assay for Vit. A and carotenoids in human and liver. Nutrition Reports International., 19: $807-813$

Parida, A. K. and Das, A. B. 2004. Effects of $\mathrm{NaCl}$ stress on nitrogen and phosphorous metabolism in a true mangrove Bruguiera parviflora grown under hydroponic culture. J. Plant Physiol., 161: 921-928.

Pelah, D., Sintov, A. and Cohen, E. 2004. The effect of salt stress on the production of canthaxanthin and astaxanthin by Chlorella zofingiensis grown under limited light intensity. World $J$. Microbiol. Biotechnol., 20: 483-486.

Qiu, Z. and Macrae, T. H. 2008. ArHsp22, a developmentally regulated small heat shock protein produced in diapausedestined Artemia embryos, is stress inducible in adults. FEBS J., 275(14): 3556-66.

Selye, H. A. 1936. A syndrome produced by diverse nocuous agents. Nature, 138: $32 \mathrm{pp}$.

Soejima, T., Katayama, T. and Simpson, K. L. 1980. International study on Artemia-XII. The carotenoid composition of eight geographical strains of Artemia and the effect of diet on the carotenoid composition of Artemia. In: Persoone, G., Sorgeloos, P., Roels, O. and Jaspers, E. (Eds.), The brine shrimp Artemia, vol. 2, Physiology, biochemistry, molecular biology. Universa Press, Wetteren, Belgium, p. 613-622.

Sorgeloos, P., P. Lavens, P. Leger, W. Tackaert and D. Versichele 1986. Manual for the culture and use of brine shrimp Artemia in aquaculture. The Belgian Administration for Development Cooperation. The Food and Agriculture Organization of the United Nations. Faculty of Agriculture, State University of Ghent, Belgium, 319 pp.

Tolasa, S., Cakli, S. and Ostermeyer, U. 2005. Determination of astaxanthin and canthaxanthin in salmonids. Europ. Food Res. Technol., 221: 787-791.

Vikas, P. A., Sajeshkumar, N. K., Thomas, P. C., Chakraborty, K. and Vijayan, K. K. 2012. Aquaculture related invasion of the exotic Artemia franciscana and displacement of the autochthonous Artemia populations from the hypersaline habitats of India. Hydrobiologia, 684: 129-14.

Vikas, P.A., Chakraborty, K., Sajeshkumar, N. K, Thomas, P. C., Sanil, N. K. and Vijayan, K. K. 2014. Quality of six Indian populations of Artemia franciscana for larval finfish culture, J. Appl. Aquac., 26: 3, 271-291.

Wimmer, M. A., Muhling, K. H., Lauchli, A., Brown, P. H. and Goldbach, H. E. 2003. The interaction between salinity and boron toxicity affects the subcellular distribution of ions and proteins in wheat leaves. Plant, Cell Environ., 26: 1267-1274.

Yancey, P. H., Clark, M. E., Hand, S. C., Bowlus, R. D. and Somero, G. N. 1982. Living with water stress: evolution of osmolyte systems. Science, 217: 1214-1222. 